УДК 347.1

\title{
ПРАВО НА ИСК О ПРИЗНАНИИ НЕДЕЙСТВИТЕЛЬНЫМИ МНИМЫХ И ПРИТВОРНЫХ СДЕЛОК
}

\author{
Корсун Александра Сергеевна \\ ФГАОУ ВО «Дальневосточный федеральный университет»
}

\begin{abstract}
Аннотация: В настоящей статье рассматривается субъектный состав лиц, имеющих право на подачу иска о признании недействительными мнимых и притворных сделок и применении последствий их недействительности. Анализируются особенности подачи иска лицами, не являющимися сторонами сделки.
\end{abstract}

Ключевые слова: притворная сделка, мнимая сделка, право на иск.

\section{RIGHT TO CLAIM FOR INVALIDATION OF FICTITIOUS AND SHAM TRANSACTIONS}

\section{Korsun Aleksandra Sergeevna}

\begin{abstract}
This article deals with the subject composition of persons who have the right to file a claim for invalidation of fictitious and sham transactions and the application of the consequences of their invalidity. The features of filing a claim by persons who are not parties to the transaction are analyzed.
\end{abstract}

Key words: sham deals, fictitious deals, right to claim.

Учитывая, что мнимая и притворная сделка законодателем отнесены к категории ничтожных, следуя нормам действующего гражданского законодательства обращаться в суд за признанием таких сделок недействительными нет необходимости.

Но в реальности как мнимые, так и притворные сделки со стороны воспринимаются как действительные, пока не доказано обратное.

Учитывая вышеизложенное, вопрос о субъектном составе лиц, имеющих право обратиться в суд за признанием недействительной мнимой или притворной сделки и (или) применении последствий её недействительности остаётся актуальным. 
Так как само по себе «право на иск» может рассматриваться в разных значениях как с материальной, так и с процессуальной точки зрения (право на предъявление иска, право на рассмотрение дела по существу, право на благоприятное судебное решение) [1], для целей данного исследования будем рассматривать его не только как формальное право предъявить исковое заявление в суд, но и как встроенное в него право на принятие иска к производству судебным органом.

Поскольку законодатель отнёс мнимые и притворные сделки к категории ничтожных, обратимся к норме, устанавливающей право на иск в отношении названной категории сделок.

Ранее действовавшая редакция Гражданского кодекса Российской Федерации (далее - ГК РФ) дозволяла обратиться с требованием о применении последствий недействительности сделки любому заинтересованному лицу (ч. 2 ст. 167 ГК РФ в ред. № 58 от 23.07.2013). Такая формулировка нормы была вполе понятна и недвусмысленна.

Федеральным законом от 07.05.2013 № 100-Ф3 статья 166 ГК РФ дополнена пунктом 3, согласно которому требование о применении последствий недействительности ничтожной сделки предоставлено право предъявлять стороне сделки, а в предусмотренных законом случаях также иному лицу.

При этом лицо, заявляющее требование о признании сделки недействительной, должно иметь охраняемый законом интерес (абз. 2 п. 3 ст. 166 ГК РФ).

Неоднозначность формулировок нормы в части субъектов («иное лицо», «лицо, имеющее охраняемый законом интерес»), имеющих право обратиться в суд, вызвало ряд дискуссий, а также повлияло на формирование судебной практики.

Разъясняя обсуждаемую норму, Верховный Суд РФ указал, что иск лица, не являющегося стороной ничтожной сделки может быть удовлетворён, если гражданским законодательством не установлен иной способ защиты права этого лица. При этом в исковом заявлении такого лица должно быть указано право (законный интерес), защита которого будет обеспечена в результате возврата каждой из сторон всего полученного по сделке, в противном случае суду предписано оставить иск без движения (п. 78 Постановления № 25) [2].

Комментируя указанную позицию высшей судебной инстанции, В.А. Белов пришёл к выводу, что Верховный суд «констатировал субсидиарное 
значение иска третьего лица о применении последствий недействительности ничтожной сделки» [3], которое, по мнению указанного автора, является новым законоположением, дополняющим Кодекс.

Действительно, обсуждаемым пунктом Верховный суд создал как материальную, так и процессуальную норму.

При этом, по нашему мнению, формулировка п. 78 Постановления № 25 [2] исключает из числа субъектов, которым предоставлено право требования применения последствий недействительности ничтожной сделки, лиц, не являющихся сторонами притворной сделки, но чьи права нарушены такой сделкой.

И, верно, к притворной сделке не применяются правила о двухсторонней реституции, ведь закон предписывает в качестве последствия недействительности притворной сделки применять правила, относящиеся к прикрываемой сделке с учётом её существа и содержания (ч. 2 ст. 170 ГК РФ).

Например, при обращении в суд с иском о применении последствий недействительности договора о совместной деятельности, прикрывающего договор аренды, суду надлежит квалифицировать правоотношения между сторонами как арендные с применением правил, относящихся к договору аренды. При этом арендованное имущество не выбывает из пользования арендатора.

При таких обстоятельствах лицо, чьи права нарушены притворной сделкой, объективно не имеет возможности исполнить требования п. 78 Постановления № 25 [2] и указать в иске, как его права будут восстановлены в результате возврата каждой из сторон всего полученного по сделке. Иными словами, при таких обстоятельствах требования п. 78 Постановления № 25 [2] не исполнимы, а иск такого лица не подлежит принятию к производству судом.

Данный пробел в правовом регулировании необходимо устранить, поскольку стороны притворной сделки в большинстве случаев преследуют цель скрыть свою реальную волю от третьих лиц, и именно третьи лица, права и законные интересы которых нарушены, обращаются в суд за применением последствий недействительности притворной сделки.

Полагаем, что исключением из описанного случая может быть ситуация, когда прикрываемая сделка имеет пороки, влекущие её ничтожность по иным основаниям. В таком случае правила о двухсторонней реституции будут применимы, а требования пункта 78 Постановления № 25 [2] для третьих (заинтересованных) лиц будут исполнимы. 
То есть, право лица, потерпевшего от заключения притворной сделки и не являющегося её стороной, на подачу иска и принятие его судом к производству, ущемлено и зависит от наличия в прикрываемой сделки пороков, влекущих её недействительность по самостоятельному основанию.

Что касается права на принятие иска от лица, потерпевшего от мнимой сделки и не являющегося его стороной, то возложенная п. 78 Постановления № 25 [2] обязанность указать в иске, как его права будут восстановлены двухсторонней реституцией, представляется возможной только в случае, если стороны формально сделку исполнили.

Однако по общему правилу, реституция в отношении мнимых сделок не применяется, поскольку ч. 2 ст. 167 ГК РФ связывает применение реституции с фактом исполнения ничтожной сделки [4]. Мнимая же сделка по смыслу ст. 170 ГК РФ сторонами не исполняется, поскольку совершена лишь для вида, без намерения создать соответствующие ей правовые последствия.

Таким образом, лицо, не являющееся стороной мнимой сделки и потерпевшее от её заключения, по смыслу п. 78 Постановления № 25 [2] также ограничено в праве на подачу иска.

Резюмируя вышеизложенное, считаем, что с целью восполнения пробела в регулировании права на подачу и принятие иска о признании недействительной мнимой и притворной сделки и (или) применении последствий их недействительности абзац 3 п. 78 Постановления № 25 [2] следует изложить в следующей редакции:

«В исковом заявлении такого лица должно быть указано право (законный интерес), защита которого будет обеспечена в результате возврата каждой из сторон всего полученного по сделке либо применения последствий недействительности мнимой или притворной сделки. Отсутствие этого указания в исковом заявлении является основанием для оставления его без движения (статья 136 ГПК РФ, статья 128 АПК РФ)».

\section{Список литературы}

1. Буркова О. Иск о признании сделки недействительной как форма злоупотребления правом [Электронный ресурс]. - Режим доступа URL: https://elibrary.ru/download/elibrary_24217203_41475503.pdf (17.11.2020)

2. Постановление Пленума Верховного Суда РФ от 23.06.2015 № 25 «О применении судами некоторых положений раздела I части первой 
Гражданского кодекса Российской Федерации» - Доступ из СПС «КонсультантПлюс». - Текст : электронный.

3. Белов В.А. «Двадцать пятое» Постановление Пленума: толкование или... законодательство? - Доступ из СПС «КонсультантПлюс». - Текст : электронный.

4. Апелляционное определение Санкт-Петербургского городского суда от 18.06.2018 № 33-10763/2018 по делу № 2-476/2017 [Электронный ресурс]. Режим доступа URL: https://kad.arbitr.ru/Document/Pdf/9f995a84-72e6-4819-a4a409af4e06c1da/ea7b0a03-96b9-4e65-97ac-fa0d0e2b0173/A70-5326-2011_20121018 _Reshenija_i_postanovlenija.pdf?isAddStamp=True (17.11.2020)

(C) A.C. Корсун, 2021 